\title{
An Integration of Pedological and Geomorphological Elements of the Batoque River Hydrographical Sub-Basin, Hidrolândia/Ce
}

\author{
Ana Mesquita Paiva \\ EInatan Bezerra de Souza \\ Ernane Cortez Lima \\ .Universidade Estadual Vale do Acaraú - UVA \\ (Acaraú Valley State University)
}

\begin{abstract}
This work describes both a pedological and geomorphological relation of the Batoque river hydrographical sub-basin, Hidrolândia/CE, located in Hidrolândia, Ceará.In order to have this paper developed, practical and conceptual studies were initially considered through a systemic approach and, soon after, a fieldwork followed by another stage of analysis of geomorphological elements based on the relief and natural resources dynamism in the pursuit of a thorough diagnosis settlement regarding pedological aspects in that area. With regard to the collected results, it is understood that the geomorphological subdivisions identified in that sub-basin are meaningful when compared to the semi-arid reality. The established quadrant to this research comprises three geomorphological units represented, respectively, by pediplains (Sertaneja Depression), the Batoque river alluvial plain and inselbergs in addition to four types of soils throughout its extension, namely Planosols, Fluvic Neosols, Litholic Neosols and Luvisols. As an overview of the final considerations, it is possible to be affirmed that the characteristics of this research encompass specificities worthy of a deeper study about thearea dynamism.
\end{abstract}

Keywords: Hydrographical Sub-Basin; Geomorphology; Soils.

\section{Introduction}

Geomorphology is a physical geography's subdivision that is responsible to study the forms of relief, in a consistent and orderly manner, in their exogenous and endogenous processes basing itself on laws that determine the origin and evolution of such forms. The geomorphological study tends to analyze two modifying factors of landscapeswhich may be modelers (past and current climates, vegetation and soils) and formers of relief (tectonic and geology).

Flores (2012), considers geomorphology as the science that studies the forms of relief and the processes that act on the surface and it has been evolving due to the use geoprocessing techniques from the use of the Sistema de Informação Geográfica (SIG) (Geographical Information System) to conduct works related to the use and occupation of lands besides assisting these environments planning and management. For Lima (2012), environmental planning is had as an environmental policy toolused to create guidelines and to plan the territory use.

Christofoletti (1989) understands geography as the science that studies the forms of relief, as well as their origin, morphological characteristics and lithological basis besides shaping and controlling processes.

Different kinds of soils are presented based on a pedological and geomorphological disposition. Knowing that pedology is the branch of geographical science that is responsible for verifying and characterizing types of soils and it is entirely linked to the relief, a deeper study of bibliographical knowledge concerning this topic was conducted.The soils department from theUniversidade Federal do Ceará (UFC) (The Federal University of Ceará) (2005) states that soilsare made up of a complex body whose origin and development are determined by the so-called formation of soil factors. One of these factors is the material of origin, which is usually a solid and mineralcompressed material, that later becomes soil configured into an unbound and inconsistent aspect. These solid materials are rocks that, in general, impress different characteristics on the soil, even on the old ones (weathered).

Lima (2012) states that, in the narrowest sense, the soil is an unconsolidated mineral and/or organic, porous and finely grained material whose particular nature and properties are inherited from the interaction of pedogenetic processes with environmental factors involving the following variables: source material, climate, living organisms, relief and time. In this way, soils are able to give life to superior terrestrial plants. Soil can be described by its various properties, among them: mineral composition, shear resistance, pore size, nutrient content, among others, which are related to properties and characteristics of its colloidal components and oxides and hydroxides concentrated in the clay-mineral constituents, as well as the size of the grains. 
In this connection, the importance of conducting this research is given by the increase in the demand for geomorphological contents in projects toward the different planning types that seek to present a project together with public bodies either in local or regional scale, principally when it is about plans for hydrographical sub-basins, as it is the case of the Batoque river hydrographical sub-basin, Hidrolândia/CE.

Such study pursues a meaningful knowledge about the geomorphological and pedological constitution and its dynamism taking into consideration the Batoque river hydrographical sub-basin, which is located in the northwest area of Ceará and situated in the SUDENE/DSG charts SB.24-V-B-I (Santa Quitéria) SB-24-V-B-IV (Tamboril), what is part of the Acaraú basin hydrographical system.It has its area within the limits of the municipality of Hidrolândia. The Batoque river runs through the urban area of Hidrolândia in its medium course.

\section{Development}

This research is based on the General System Theory applied to geographical science, which is grounded on the mutual relation among its components, and seeks to analyze phenomena mainly through the organization and inter-relation among their constitutive elements.

Troppmair (1989) stresses that the General System Theory was initially developed in the United States of America in thermodynamics (1929) by R. Defay, subsequently implemented in biology by Ludwig Von Bertalanffy, in 1932, and presented in an inaugural form in 1937 in the philosophical seminar of Chicago.

For Thornes and Brunsden (1977), the system is "a set of objects or attributes and their relations, organized to perform a particular function". Based on thisstatement, the system is understood as the operator thatreceives input and turns it into output for a certain period of time.

Hydrographical sub-basins are inserted exactly in this context, where there is a continuous flux of energy and matter among the elements, and they are, somehow, in a dynamic balance affected by the socioeconomic action effects with characteristics liable to be measured and analyzed. Therefore, it is suitable for environmental planning and management. Tonello (2005) declares that hydrographical basins must be considered as an environmental planning and management unit that seeks to preserve hydric resources. For Botelho and Silva (2004), hydrographical basins are recognized since the late 1960s as analysis spatial units by physical geography.However, it is had nowadays as an analysis unit, where the systemic and integrated conception of the environment is implicit, making possible to know and evaluate its components, processes and interactions.

Nevertheless, the systemic approach in hydrographical sub-basins enables the analysis of the physical space in a way that is possible to establish necessary information to apply environmental planning and management when in face of socioeconomic activities which has been developed throughout the historical process of their use and occupation.

The adopted methodology consists of specific bibliographic surveys starting in the theoretical approach from a systemic and integrated view of the area, where is found located in the northern region of Ceará, more specifically in the municipality of Hidrolândia. Furthermore, books and scientific papers were examined and associated with field observations in addition to the access to Google Earth Pro. Fieldworks were essential in the course of the development of this research and they comprised all the spatial demarcation made in the Batoque river hydrographical sub-basin.

The first fieldworks were carried out to recognize and verify the truth of information using some previously organized databases as an aid to be used in further stages. Some matrix charts from SUDENE/DSG were used in fieldwork, namely SB.24-V-B-I (Santa Quitéria) SB-24-V-B-IV (Tamboril). Besides, a socio-environmental survey was made from its top course, where the main Batoque river springs are located, to its mouth, where it flows out intothe Paulo Sarasate reservoir (Araras reservoir). In addition to it, some cartographical basis were taken into account with the help of preliminary maps of the area, which were drawn up using software designed for this purpose.

\subsection{The Batoque river hydrographical sub-basin geomorphology}

The Batoque river hydrographical sub-basin landscape displays different characteristics, which are naturally integrated among themselves. Its geomorphology is composed of Sertaneja Depression, the Batoque river alluvial plain and the presence of inselbergs besidespresenting a semi-arid hot tropical climate, irregular and poorly distributed rains from January to May and the lack of them in the other seven months of the year. For a biological exploration, four kinds of soils were identified in the territory of this sub-basin, namely Planosols, Fluvic Neosols, Litholic Neosols and Luvisols. These are the characteristics susceptible to affect directly in socioeconomic and cultural practices developed in the considered area, just like anthropic actions are responsible for lots of changes in the local ecosystem. In this manner, the interaction among all the elements is realized, including the human being, who is made not only an explorer agent but also part of this nature. 
The collected data proves that studies related to theoretical and methodological production accumulated by specific branches of geography, in particular, geomorphology and pedology which are branches of this science capable of providing integrative elements of natural elements. Araújo (et. al., 2005), says that geomorphology has as the principal object of study the forms of relief and the investigationof processes that originated such forms and material considered by the processes in order to result in different shapes. For Penteado (1975), in an etymological conception, geomorphology is understood to be the science responsible to study the shapes of the land. In accordance with Claudino-Sales and Peulvast (2007), in a regional context, the formation and evolution of the northeastern relief is conditioned to events that originated the continental shore of Ceará, which started in the late of the Jurassic period.Between the Jurassic and Barremian periods, there were distensive efforts responsible to prepare the rupture between South America and Africa, which resulted in a series of rifts in the system Cariri/Potiguar. The established quadrant to this research comprises three geomorphological units which are represented, respectively, by pediplains (Sertaneja Depression), the Batoque river alluvial plain and inselbergs. To describe the geomorphological units in that area, it was considered the criteria used in the identification of units on a regional scale.

The Sertaneja Depression, or pediplain, is the shape that has the most expressiveness given its extension, as shown in figure 01.

Figure 1: The Batoque river hydrographical sub-basin geomorphological map (Mesquita; Oliveira 2019).

According to Souza (2006), SertanejaDepressions, or pediplains, are surfaces embedded into layers of

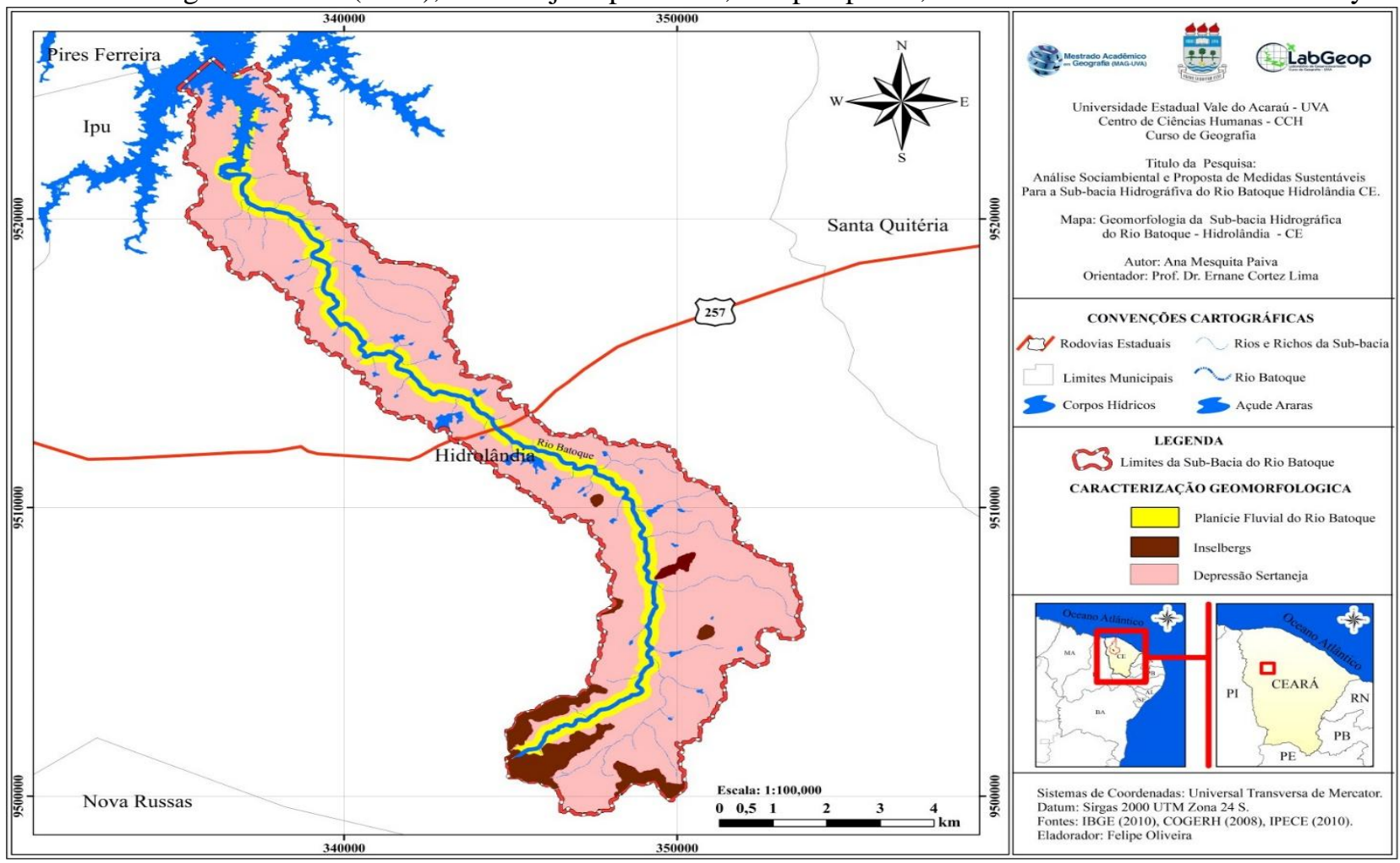

sedimentary or crystalline plateaus, with altitudes not higher than $400 \mathrm{~m}$ and accentuated lithological diversification, widely subjected to warm semiarid conditions, with strong rainfall irregularity, dense fluviometric network, weakly and moderately carved in the surface with river channels endowed with seasonal intermittency, mosaic of associated soils, being common the existence of shallow soils on the hinterland surface as well as rocky outcrops and stony soils, are extensively covered by theCaatinga vegetation, which areopen shrubs, and presents a variety of physiognomic and floristic patterns and different levels of degradation in which current use predominates the agricultural and forestry activities.

For Claudino Sales and Peulvast (2007) apud Lima (2012), a morphological-structural disposition was inherited from the Neocomian-Barremian intercontinental extension and from the Barremian-Albian equatorial transforming deformation, what resulted in the oceanic opening during the Superior Cretaceous followed by inversions of reliefs in the late of the Cretaceous period. These morphological-structural devices present the ancientpre-Cenomanian topography, which ishalf-buried in a depressed topographic position with large planing with inselbergs in the plane of 
the hinterlandsurface, in the vicinity of traces of shoulders (horsts) of rifts of the Cariri/Potiguar axis (LIMA, 2012).

As for the alluvial plains, they are the most characteristic forms of accumulation resultingfrom alluvial actions, that is, these are areas of regional differentiation in semi-arid sertões and they possess the best soil conditions and water availability besides being constituted as exception environments in semi-arid Sertaneja Depressions. Concerning their geoenvironmental potentiality, it is necessary to take into account that these areas are liable to be periodically flooded and moreover their soils are covered by riparian vegetation predominantly carnauba in their floristic community, which is a characteristic of this environmental system (SOUZA, 2000). In accordance with Rodrigues (2016), the formation process of this relief unit is tied to the transportation of matter, which is performed by fluvic systems.

In Sugio and Bigarella's view (1990), fluvial current represents, possibly, one of the most important geological agents that plays a quite relevant role not only in the shaping of the earth's surface but also in the environmental conditioning of human life. Powell (1876) apud Peulvast and Claudino Sales (2002) was one of the first people to prove the fundamental laws of the fluvial action. He established the definition for the fluvic erosion basis level and from this definition, he also formulated the idea of erosion cycle that in its final stage would lead to a peneplanation of the relief.

In Souza's viewpoint (1988), the upstream presents narrow and more excavated valleys whereas in downstream the channel tends to suffer an expansion, mainly in its low course, where the sediment accumulation is more intense.It essential to stress that the Batoque river alluvial plain is part of the second hydrographical basin in Ceará, the Acaraú basin, which has a moderate hydric reserve level despite being conditioned by semi-arid processes and having an irregular fluvic scheme and high evaporation levels (COGERH, 1988).

The geomorphological shape defined as inselbergs or monadnocks is conceptualized by Souza (2000) when he declares that shapes constituted by the selective action of degradative processes are spread around sertões and loweredrocky massifs breaking the continuity of Sertaneja Depressions, they quite often present bare cliffs with boulders.

According to Ab'Saber (2003), inselberg is a salient relief residue amid a semi-arid plain landscape and it originates from a long erosive history related to dry processes.The principal interest for this form of relief, since it is isolated inside thehinterland surface, is related in a local and general geomorphological context, as well as discussions about the most likely formation and transformation processes responsible for its propagation in the northeastern sertão.

\subsection{The Batoque river hydrographical sub-basin soils}

The soil classes that characterize the Batoque river hydrographical sub-basin area were identified through both desk work using the classification of the Sistema Brasileiro de Classificação de Solos (SIBCS, EMBRAPA 2006) (Brazilian System for Soil Classification) and fieldwork by analyzing the profile morphology, the relief's type of vegetation, the lithology type and the land potential. Through these works, four types of soils were identified in that sub-basin extension, namely Planosols, Fluvic Neosols, Litholic Neosols and Luvisols.

These soils are distributed as follows: Planosols and Litholic Neosols in the low slopes and valley bottoms of low fertility; Fluvic Neosols in the low slopes and valley bottoms with high fertility; and Luvisols predominate in the low mountainous hills, presenting medium to high natural fertility.

\section{- Planosols}

It comprises imperfectly or badly drained mineral soils with an eluvial sub-superficial or a superficial horizon with a slighter texture which strongly contrasts with the B horizon or with a conjugate abrupt transition with a notorious difference when compared to the A horizon texture and the immediately underlying and thickened B horizon, which usually has high levels of clay and slow or very slow permeability, what makes of it the horizon responsible for the formation of superimposed (suspended) water table with periodic existence and a variable presence along the year.

In lowlands, floodplains and depressions, under humid climate, Planosols are truly hydromorphic soils with a plannic horizon that presents coincidentally characteristics of Gleysols.However, in semi-arid areas and, even in areas where the soil is subjected only to a water surplus for a short period, principally under conditions of slightly wavy relief, Planosols are not even considered properly as hydromorphic soils. 
Though, it is hard to distinguish without continuous observation and in dry or rainy periods if the soil pale colors are results or not of the expression of current reduction processes. According to the map of soils of the area, Planosols are the ones that have the most expressivity in points of the riverbank.

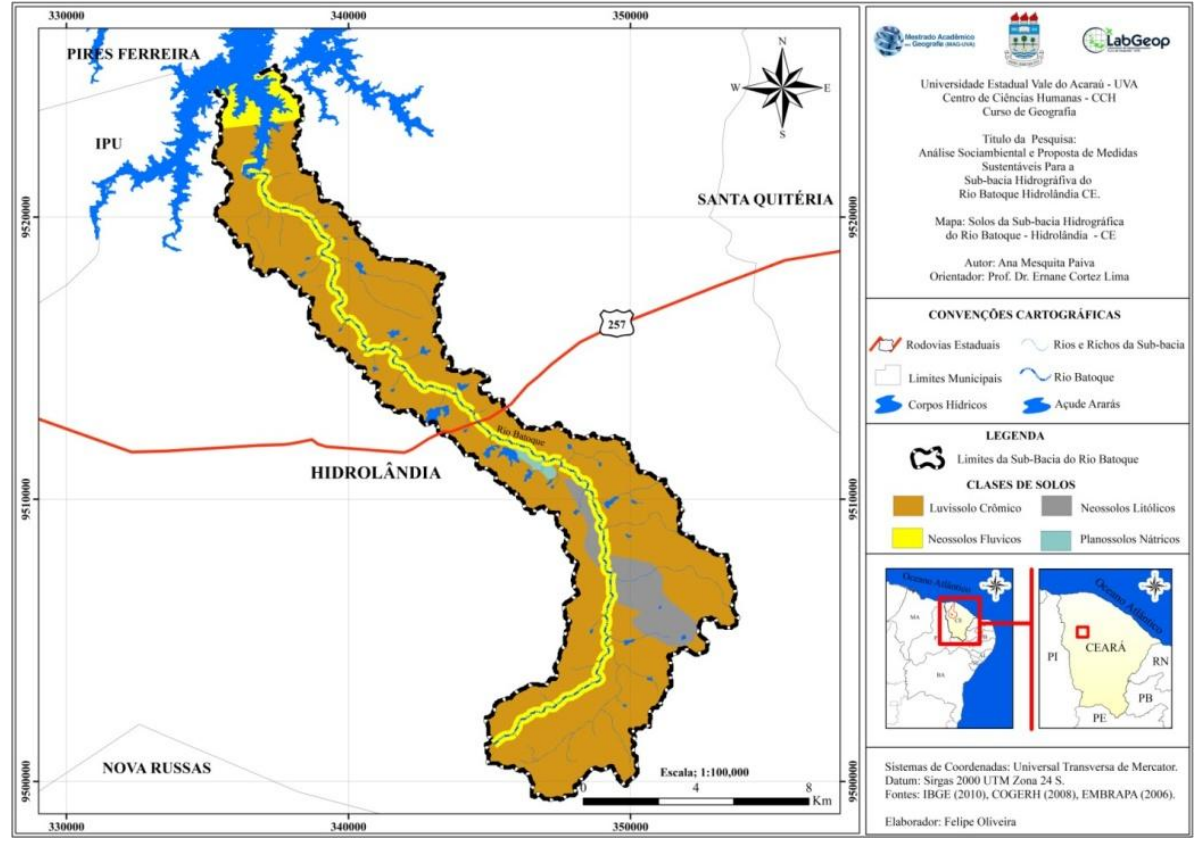

\section{- Fluvic Neosols}

These type of soil comprise those soils made up of mineral material or not so thick organic material, which do not present significant alterations in relation to the original material due to the low intensity of pedological and genetic processes action,either because of characteristics inherent in the source material itself like a greater resistance to weathering or chemical-mineral composition, or because of other formation factors (climate, relief or time), which can prevent or limitate soils to evolve.

They are deep or very deep, have a texture ranging from sandy to clayey and varyfrom moderate to imperfectly drained. From a chemical viewpoint, they have saturation and sum of high exchangeable bases, with assimilable phosphorus contents varying from medium to high and with $\mathrm{pH}$ ranging from acid to slightly alkaline. They are rich in primary components easy to be decomposed and essential to the vegetation development. The A or Ap horizon is normally weak or moderated, at times Chernozems, with a texture between sandy and clayey besides burnished colors, being sprinkled in imperfectly drained clayey soils. Fluvic Neosols are present in the area following the Batoque river longitudinal profile.

\section{- Litholic Neosols}

Litholic Neosols present a great quantity of primary mineral materials and semi-weathered lumps of rock of different sizes over the subjacent rock and, for this reason, bio-climatically 113 are soils not so developed (recent), ranging from a sandy to silty texture and from moderately acidic to practically mild.They occur, also, associated with Argisols and Luvisols.

These soils are foundover the dissected areas, in slightly wavy, mountainous and even steep relief hillsides. They occupy areas with practically plain reliefs and arelittle developed, shallow and very shallow, not-hidromorphic, welldrained and rocky on surfaces. It is possible to find them in the western part of the Batoque river hydrographical subbasin and in the eastern part of the Paulo Sarasate reservoir.

\section{- Luvisols}

Luvisols involve mineral and not-hidromorphic soils with textural B horizon with high activity clay and high base saturation, immediately below A or E horizons. These soils vary from well to imperfectly drained, usually not so deep $(60 \mathrm{a} 120 \mathrm{~cm})$ with a sequence of $\mathrm{A}, \mathrm{Bt}$ and $\mathrm{C}$ horizons and a notorious difference between $\mathrm{A}$ and Bt horizons due to the texture contrast, color and/or structure between them. The transition to the textural B horizon is clear and abrupt, and a large part of soils from this type has an abrupt textural change. They may present or not stoniness in their 
surfaces and a solodic or sodium character in their sub-surfaces. In the studied area, these soils are the most present one outstanding all over the sub-basin in the eastern, southeastern and south ends also almost reaching the ends of the subbasin in some parts. Observe the figures 2 and 3 which shows the soils found in the Batoque river hydrographical subbasin, Hidrolândia/CE.

Figure 2: The Batoque river hydrographical sub-basin soils map (Mesquita; Oliveira 2019)

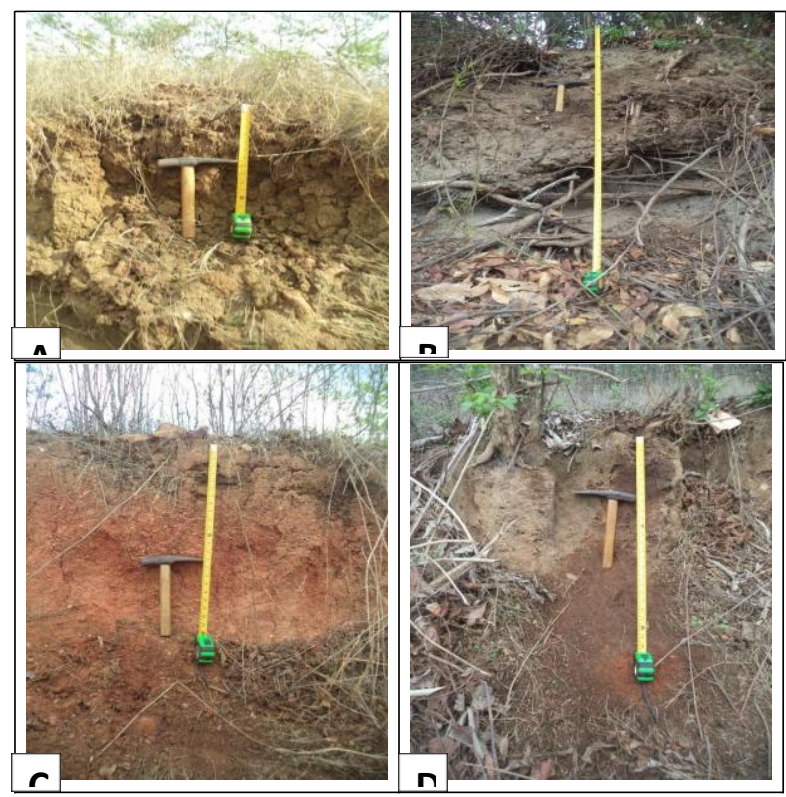

Figure 3: Soil profiles found in the Batoque river hydrographical sub-basin (A - Planosols; B - Fluvic Neosols; C Litholic Neosols; D - Luvisols) (Mesquita 2019)

\subsection{The pedological and geomorphological integration in the Batoque river hydrographical sub-basin}

By being attentive to the studied area, it gets clear the semi-arid environmental reality as here presented, while the noticed landscapes can report to the nature elements delivering conditions to the use and occupation of the hydrographical sub-basin area, as in the case of the municipality of Hidrolândia/CE, which experiences a closeness to the semi-arid naturewhile develops agricultural activities consequently boosting the local economy and complementing the residents livelihood. Therefore, it is necessary a reflexion about the spatiality of such economic activity that characterizes the semi-arid region frequently shaping landscapes in a social pattern found in different environments.

When associating the nature elements, in special the soil, it is possible to find different types before the unique pedological characteristics presented by each relief. According to Lima (2007), these diversities in the type of soils are caused by some factors like climate, biological factors, bedrock, relief action and elapsed time, being the climate and bedrock action the principal factors which determine these soils formation.

If the cartographical material in this research presented is thoroughly considered, it is possible to notice that the types of soils there found are completely associated to geomorphological shapes, making clear the existence of a systemic relation among those geo-environmental characteristics, what can be analyzed in table 1 below.

Table 1: Pedological-Geomorphological interaction (Mesquita 2019)

\begin{tabular}{|l|l|l|}
\hline Geomorphological Units & Types of Soils & Locationinside the sub-basin \\
\hline Pediplain & Luvisols, Planosols. & From Northto South. \\
\hline Batoque river alluvial plain & Fluvic Neosols. & West. \\
\hline Inselbergues & Litholic Neosols. & South. \\
\hline
\end{tabular}

For an environmental analysis or even a socio-environmental one, the data in this research are strongly relevant since the relief and the type of soil impacts directly in the other characteristics found in the outstanding hydrographical subbasin. Therefore, it reflects on how and in what society can invest in a subsistence production amongst other factors.

\section{Final Considerations}


Therefore, this research concludes that reflect upon the hydric resources matter in the northeastern semi-arid from a pedological and geomorphological study of the Batoque river hydrographical sub-basin, Hidrolândia/CE, is extremely important since the soils and geomorphology are some of the natural elements that affect the most the dynamism of the nature. Thus, the occurrence of this work arose with the purpose of developing an environmental and social planning of the area.

Starting with this assumption, it is emphasized that the Batoque river hydrographical sub-basin is had as an important hydrographical system once it is used by part of the local resident as a subsistence source taking into consideration that close to its springs occurs the use of the area for subsistence farming, the main river runs through the urban area of the municipality of Hidrolândia besides supplying the Acaraú river dam (Paulo Sarasate), which provides water to other municipalities in the state of Ceará.

Studies about hydrographical basins become important because they have limits, requiring this way the proposing of some measures to ease the impacts caused by the intensive use of natural resources by the people causing landscape mischaracterization.

\section{Bibliographical References}

ARAÚJO, G. H. de S. (2005). Gestão ambiental de áreas degradadas. Rio de Janeiro: Bertrand Brasil.

BOTELHO, R.G.M.; SILVA, A.S. Bacia hidrográfica e qualidade ambiental. In: VITTE, A.C.; GUERRA, A.J.T. (orgs.). Reflexões sobre a geografia física no Brasil. Cap. 6. p. 153- 188. Rio de Janeiro: Bertrand Brasil, 2004.

CHRISTOFOLETTI, A. Aplicabilidade do conhecimento geomorfológico nos projetos de planejamento. In:GUERRA, A. J. T.; CUNHA, S. B. Geomorfologia - 2a ed. - São Paulo: Editora Blucher, 1980, p. 102- 110.

CLAUDINO SALES, V; PEULVAST, J P Evolução Morfoestrutural do Relevo da Margem Continental do Estado do Ceará, Nordeste do Brasil -Caminhos de GeografiaRevista on line UFU- Fev/2007.

FLORES, Diego Moraes. Análise Geomorfológica da Bacia do Ribeirão Balainho/ Suzano (SP). São Paulo, 2012.

GUIMARÃES, L. S.; LIMA, E. C. Levantamento Geoambiental dos Componentes Físico-Naturais da Sub-Bacia Hidrográfica Semiárida do Nordeste do Brasil, Rio Itacolomi-CE. Revista da Casa da Geografia de Sobral (RCGS), v. 21, p. 1104-1118, 2019.

LIMA, E.C. Planejamento ambiental como subsídio para gestão ambientalda bacia de drenagem do açude Paulo Sarasate Varjota - Ceará. Tese(Doutorado em Geografia) - Programa de Pós-Graduação em Geografia, Universidade Federal do Ceará - UFC, 2012.

LIMA, E. C. Análise geoambiental do Vale do Riacho Boqueirão - Sobral/CE. Revista Homem, Tempo e Espaço. Sobral (CE), setembro de 2007.

NASCIMENTO, W.M.; VILLAÇA, M.G. Bacias hidrográficas: planejamento e gerenciamento. Revista eletrônica da Associação dos Geógrafos Brasileiros (AGB), Três Lagoas, n. 7, maio de 2008.

PENTEADO, M. M. Fundamentos de geomorfologia. Rio de Janeiro, IBGE, 1974.

RODRIGUES, J.M.D.; LIMA, E. C. . Análise dos Sistemas Ambientais da Sub-Bacia Hidrográfica do Rio Bom Jesus: Diretrizes para o Planejamento e Gestão Ambiental. Espaço Aberto (UFRJ), v. 6, p. 89-102, 2016.

RODRIGUES, J.M.D.; LIMA, E. C. . Análise dos Sistemas Ambientais da Sub-Bacia Hidrográfica do Rio Bom Jesus - Taperuaa - CE Revista da Casa da Geografia de Sobral (RCGS), v. 17, p. 60-79, 2015.

SILVA, D. P.;LIMA, E. C . Impactos Ambientais no Alto Curso dasub-bacia Hidrográfica do Rio Batateiras na Região Sul do Estado do Ceará. Revista da Casa da Geografia de Sobral (RCGS), v. 21, p. 1091-1103, 2019.

SOUZA, Marcos José Nogueira de. Contexto geoambiental do semi-árido do Ceará: problemas e perspectiva. In: FALCÃO SOBRINHO, José e COSTA FALCÃO, Cleire Lima da. (Org.) Semi- Árido: Diversidades, Fragilidades e Potencialidades. Sobral Gráfica, Sobral, 2006.

SOUZA, M.J.N. Bases naturais e esboço do zoneamento geoambiental do estado do Ceará. In: LIMA, L.C.; MORAIS, J.O.; SOUZA, M.J.N. (org.). Compartimentação territorial e gestão regional do Ceará, p. 5-104. Fortaleza: Editora FUNECE, 2000.

THORNES, J.B. \& BRUNDSDEN, D. - 1977 - Geomorphology \& time. New York, Wiley. 208p

TONELLO, K.C. Análise hidroambiental da bacia hidrográfica das Pombas, Guanhães, MG. Tese (Doutorado em Ciência Florestal) - Programa de pós-graduação em ciência florestal, Universidade Federal de Viçosa, 2005.

TROPPMAIR, H. Biogeografia e Sistemas: sistemas urbanos. In: Biogeografia e Meio Ambiente. 6. ed, Rio Claro: UNESP, 2004. p.126-167. 